Political Organizations 
PRINCETON STUDIES IN A M R I CAN POLITICS:

H I S TORICAL, INTERNATIONAL, A N

COM PARA T IVE PERS PECTIVES

\section{SERIES EDITORS}

I RA KATZNELSON, MARTIN SHEFTER, THEDASKOCPOL

Labor Visions and State Power: The Origins of Business

Unionism in the United States

by Victoria C. Hattam

The Lincoln Persuasion: Remaking American Liberalism

by J. David Greenstone

Politics and Industrialization: Early Railroads in the United States and Prussia by Colleen A. Dunlavy

Political Parties and the State: The American Historical Experience by Martin Shefter

Prisoners of Myth: The Leadership of the Tennessee Valley Authority, 1933-1990 by Erwin C. Hargrove

Bound by Our Constitution: Women, Workers, and the Minimum Wage by Vivien Hart

Experts and Politicians: Reform Challenges to Machine Politics in New York, Cleveland, and Chicago

by Kenneth Finegold

Social Policy in the United States: Future Possibilities in Historical Perspective by Theda Skocpol

Political Organizations

by James Q. Wilson 


\section{POLITICAL}

\section{ORGANIZATIONS}

B Y

JAMES Q. WILSON

PRINCETON UNIVERSITY PRESS

PRINCETON, NEW JERSEY 
Copyright (C) 1995 by Princeton University Press Published by Princeton University Press, 41 William Street, Princeton, New Jersey 08540

In the United Kingdom: Princeton University Press, Chichester,

West Sussex

All Rights Reserved

\section{Library of Congress Cataloging-in-Publication Data}

Wilson, James Q.

Political organizations / by James Q. Wilson.

p. cm. - (Princeton studies in American politics)

Originally published: New York: Basic Books, 1974.

Includes bibliographical references and index.

ISBN o-691-04385-X (pbk.)

1. Lobbying-United States. 2. Pressure groups-United States.

I. Title. II. Series.

JK1118. W54 1995

$324^{\prime} \cdot 4^{\prime} 0973-\mathrm{de} 20$

$95^{-14653}$

Princeton University Press books are printed on

acid-free paper and meet the guidelines for permanence and

durability of the Committee on Production Guidelines for Book

Longevity of the Council on Library Resources

Printed in the United States of America by Princeton Academic Press

13579108642 